\title{
Ammonoid diversification in the Middle Triassic: Examples from the Tethys (Eastern Lombardy, Balaton Highland) and the Pacific (Nevada)
}

\author{
Attila Vörös* \\ Hungarian Academy of Sciences; Hungarian Natural History Museum; Eötvös Loránd University \\ Research Group for Paleontology, Budapest, Hungary
}

The diversity dynamics of the Anisian ammonoids is analyzed in terms of generic richness and turnover rates in one North American (Nevada) and two western Tethyan (Eastern Lombardy, Balaton Highland) regions. Two pulses of diversification are outlined: one in the middle Anisian (Pelsonian) and another near the end of the late Anisian (late Illyrian). The Pelsonian global diversification is interpreted as an effect of global sea-level rise. In the early late Anisian the ammonoid generic richness definitely decreased both in the western Tethys and in Nevada. The latest Anisian peak of ammonoid diversity was low in Nevada, which is explained by the uniform local sedimentary environment and the absence of major global changes. In the western Tethys the late Illyrian diversity peak was very prominent: ammonoid generic richness, turnover and proportion of originations were very high. This explosive peak is interpreted in terms of major changes of two regional environmental factors: coeval volcanic activity and the control of nearby carbonate platforms. The late Illyrian volcanic ash falls provoked a dramatic increase of ammonoid generic richness by fertilization, i.e. supplying nutrients and iron, thus increasing primary productivity in the ocean. Carbonate platform margins offered diverse habitats with new, empty niches; the microbial mats supplied suspended organic matter for the higher trophic levels and eventually the ammonoids. In the western Tethyan regions platform growth re-appeared after the end-Permian crisis, and significantly increased in the late Illyrian. This was closely followed by the remarkable increase of ammonoid generic richness. Many of the genera which originated during the late Anisian seem to be ecologically connected to the platform or peri-platform environments. It is suggested that this explosive diversity peak is a manifestation of the co-evolution of the Tethyan carbonate platforms and the ammonoids.

Key words: ammonoids, diversity dynamics, environment, Middle Triassic, Tethys, Pacific

* Corresponding address: H-1431 Budapest, P.O.B. 137, Hungary; E-mail: voros@nhmus.hu Received: October 31, 2014; accepted: December 15, 2014 


\section{Introduction}

Ammonoids nearly became extinct at the Permian/Triassic boundary but, in contrast to many other fossil groups, they recovered very rapidly after the biotic catastrophe and became perhaps the most significant group of animals in the Mesozoic seas. The Mesozoic history of the ammonoids shows two major, distinct evolutionary cycles: one in the Triassic and, after a near-extinction at the end-Triassic a second one in the Jurassic-Cretaceous (Arkell et al. 1957; House 1988). The Triassic phylogenetic radiation and diversification, recorded mostly in the group of Ceratitida, was further analyzed in detail by Tozer (1981) and recently by Brayard et al. (2009) and Balini et al. (2010).

From the beginning of the Triassic to the middle Olenekian (Smithian/Spathian boundary), during a period of 2.5 million years, the number of ammonoid families increased from 2 to 15 . In spite of two minor episodes of extinction and faunal turnover (end-Induan and mid-Olenekian) the trend of the gradual diversification continued toward the end of the Olenekian, when the number of ammonoid families reached 29 (Brayard et al. 2006, 2009). These rapid turnovers were probably caused by late phases of the voluminous end-Permian igneous event (Siberian traps) and the resulting fluctuations of the carbon cycle, climatic change, and possibly acidification of surface waters (Galfetti et al. 2007a, 2007b; Brühwiler et al. 2010). The latitudinal ammonoid diversity maximum was confined to the equatorial zone (Galfetti et al. 2007a, 2007b) but in the time of pulses of diversification, ammonoids successfully migrated to the Boreal regions (Zakharov and Popov 2014). The Olenekian/Anisian boundary interval saw the first major, true extinction of the Triassic ammonoids but subsequently, the 11 survivor families showed a rapid radiation and the number of genera increased from 37 to 84 for the late Anisian (Fig. 1).

The Anisian diversification resulted in the second highest peak of generic richness in the history of Triassic ammonoids. This ammonoid diversity maximum cannot be interpreted in the same way as the Early Triassic ones, because a crucial global environmental factor changed significantly, as reflected by the carbon isotopic ratio, which strongly fluctuated in the Early Triassic but stabilized in the Middle Triassic (Galfetti et al. 2007a; Brühwiler et al. 2010). The present paper is aimed at the documentation and interpretation of this Anisian pulse of diversification which is much less studied and understood than the Early Triassic ones.

Diversification of an animal group is usually interpreted in terms of evolutionary processes which appear at higher taxonomic levels. In the case of Triassic ammonoids, Tozer (1981; Fig. 1) showed that the pre-Spathian (middle Olenekian) and the late Anisian evolutionary turnovers were manifested by the appearance of five and three new ammonoid superfamilies, respectively. However, evolution probably works at a lower level, perhaps that of species and population level. Brayard et al. (2009) discussed two diversity-dependent diversification models: the (evolutionary-based) logistic and another (population dynamics-based) hierarchical one. Their model comparisons favored the population dynamics-based diversification model over the evolu- 
tionary-based one. The population dynamics-based model involves a niche incumbency effect (Walker and Valentine 1984) which emphasizes the importance of vacant niches in stimulating diversification. This ecological rather than evolutionary approach is favored in the present study.

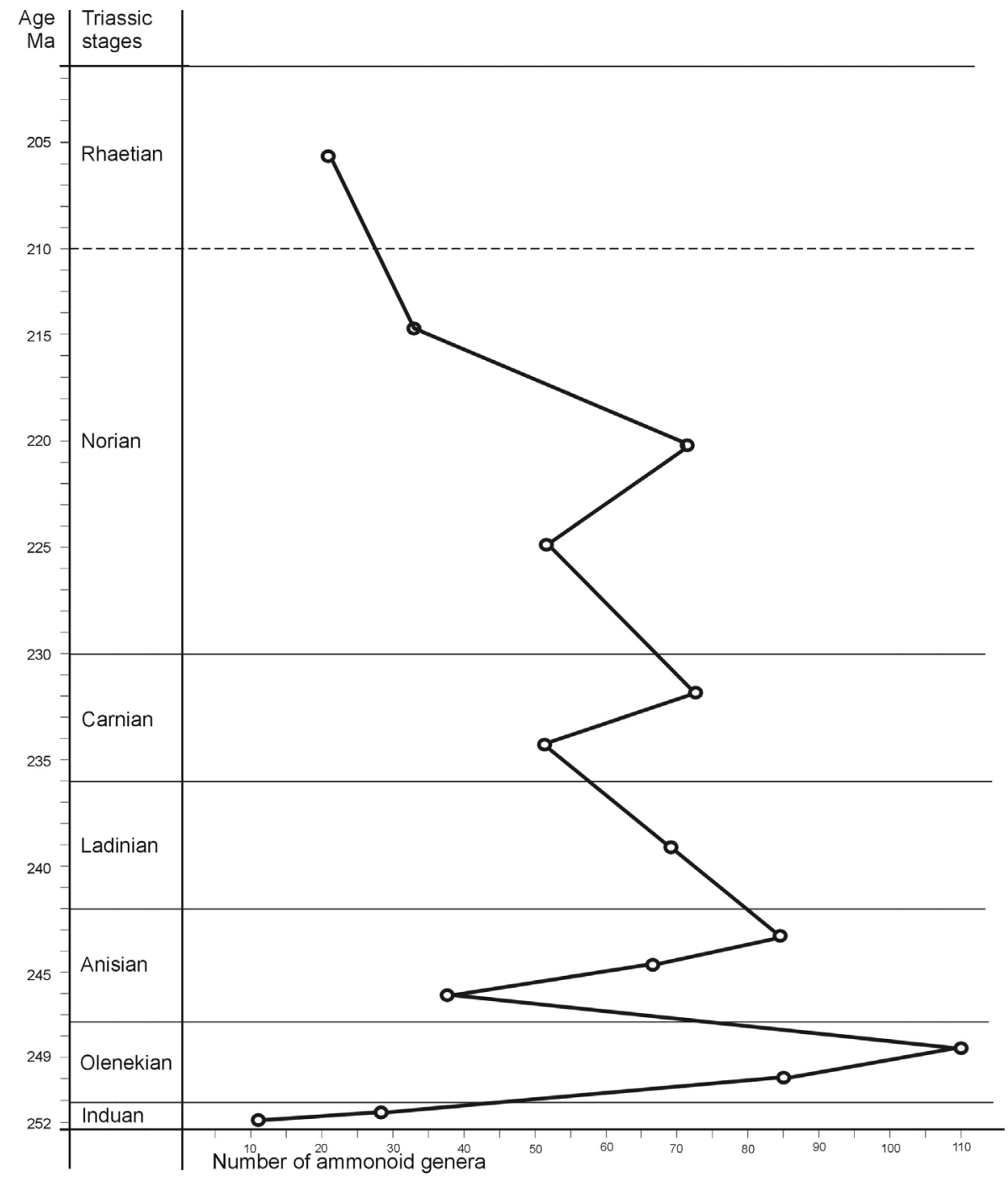

Fig. 1

Temporal changes in total generic richness of Triassic ammonoids. Data based on Brayard et al. (2009); ages from time scale by Mundil et al. (2010) 


\section{Data and methods}

Anisian ammonoids have been recorded and documented from numerous parts of the Tethyan and Circum-Pacific region. However, many of the very important, famous and well-documented ammonoid localities lack a continuous record and/or detailed stratigraphic subdivision. In many regions, diverse and properly described middle Anisian faunas are followed by scanty ammonoid assemblages in the Upper Anisian, e.g. in Spiti (Krystyn et al. 2004), in South China (Stiller and Bucher 2008) and in Arctic Asia (Dagys 2001). In other cases the ammonoid record is good but discontinuous, and the stratigraphic subdivision is rather coarse, e.g. in Canada (British Columbia: Tozer 1994) or in the Dolomites (Balini 1993; Mietto and Manfrin 1995).

Detailed and continuous stratigraphic record and reliable, modern ammonoid taxonomical works are available mainly from some of the Alpine localities and from Nevada in North America. Three areas have been selected for studying the Middle Triassic ammonoid diversification; their middle Anisian to earliest Ladinian ammonoid record forms the database of the present study.

(1) Eastern Lombardy/Giudicarie region (without the Dolomites) (Southern Alps, Italy); 51 genera, 85 species (Balini 1992a, 1992b, 1998; Brack et al. 1999, 2005; Mietto et al. 2003; Monnet et al. 2008).

(2) Balaton Highland (Hungary); 42 genera, 84 species (Vörös 1998, 2003).

(3) Northwest Nevada (USA); 47 genera, 81 species (Silberling and Nichols 1982; Bucher 1992; Monnet and Bucher 2005).

These classical Triassic ammonoid localities were recently investigated, and on the basis of bed-by-bed ammonoid collections, the respective measured sections were precisely subdivided. Their detailed stratigraphic correlation was also carried out (Monnet et al. 2008; Vörös et al. 2009; Balini et al. 2010) and this was applied in the present paper in a somewhat simplified form (Table 1). The names and the spans of the ammonoid zones and subzones partly differ in the three areas. The number of subzones recognized in the middle Anisian to earliest Ladinian interval is 16 in Eastern Lombardy, 15 in the Balaton Highland and 19 in Nevada. The palaeogeographic position of the selected areas (two in the western Tethys, one in the eastern Panthalassa) offers a possibility to compare the ammonoid diversification processes in the two distant oceanic domains.

The diversification of the ammonoid faunas, i.e. the temporal changes in taxonomic diversity, was expressed by the generic richness in the separate subzones of the respective localities. In the three areas 89 genera were recorded altogether. Species richness was also counted but not investigated further because this value is believed to be more strongly influenced by subjectivity in taxonomy (i.e. species concepts of different authors). The occurrences of particular genera in the subzones in Eastern Lombardy, in the Balaton Highland and in Nevada, respectively, are shown by range charts in Figs 2-4, which also show the turnover data at the individual subzonal boundaries. 
Ammonoid diversification in the Middle Triassic 323

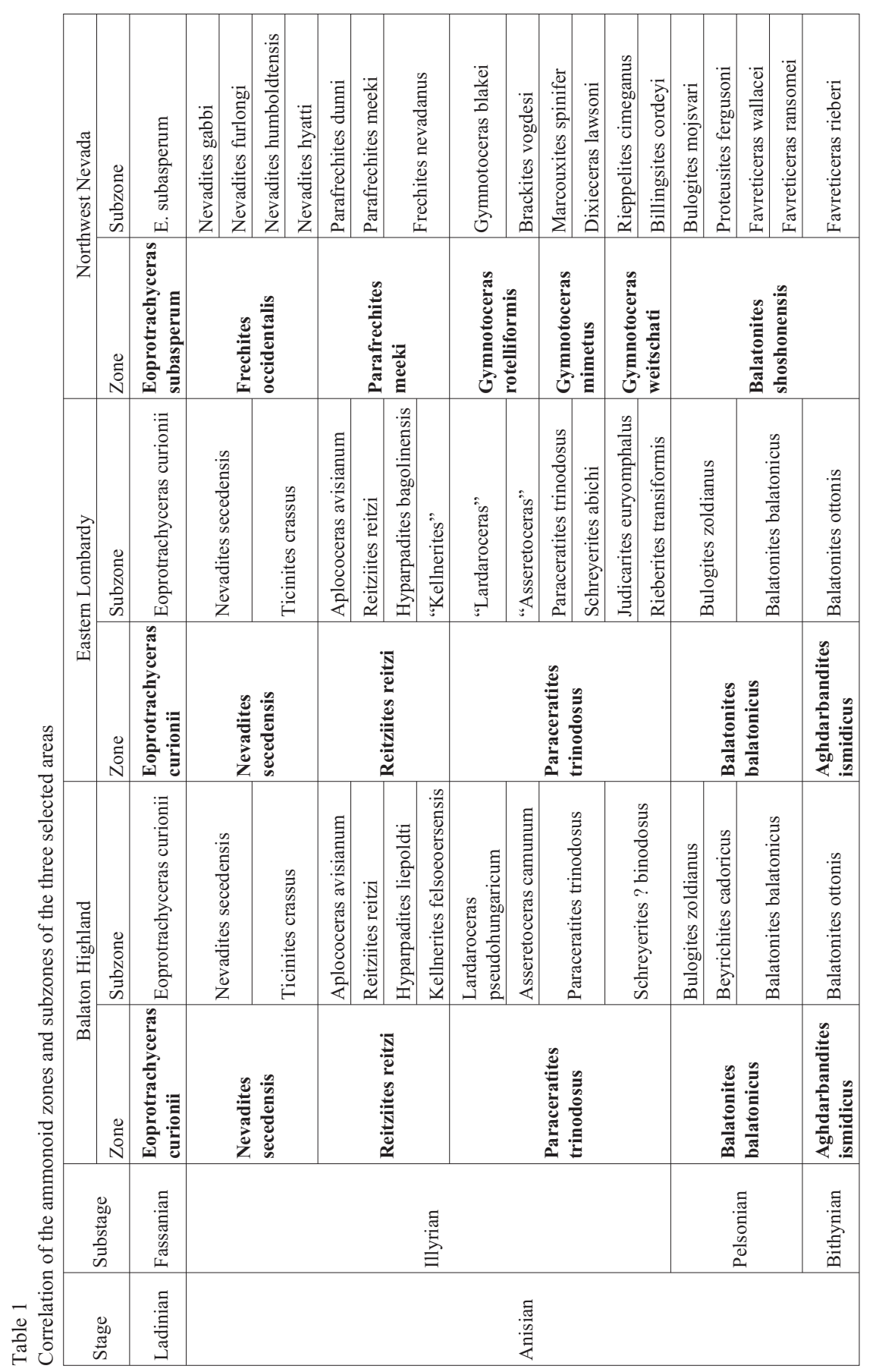

Central European Geology 57, 2014 


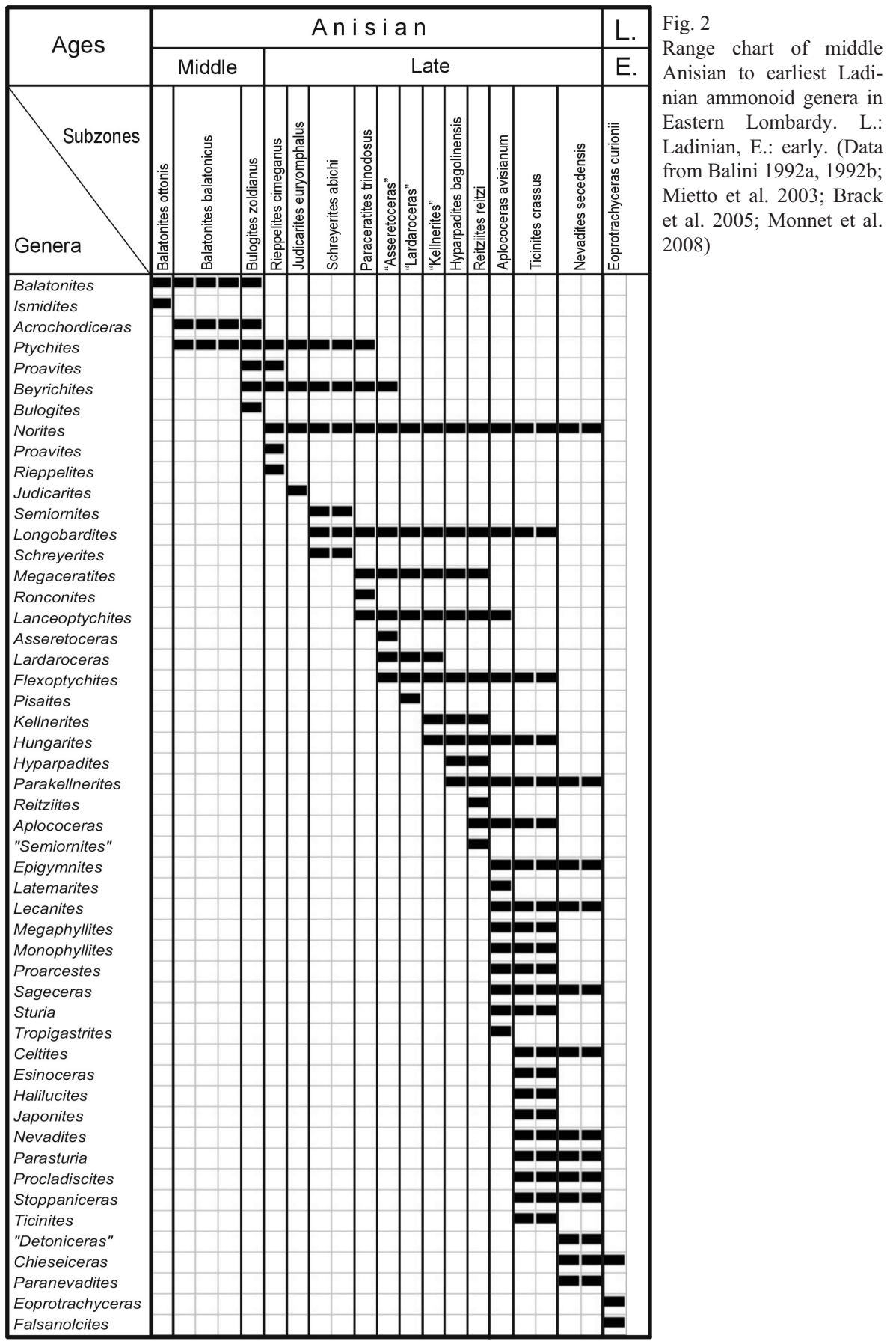

Central European Geology 57, 2014 


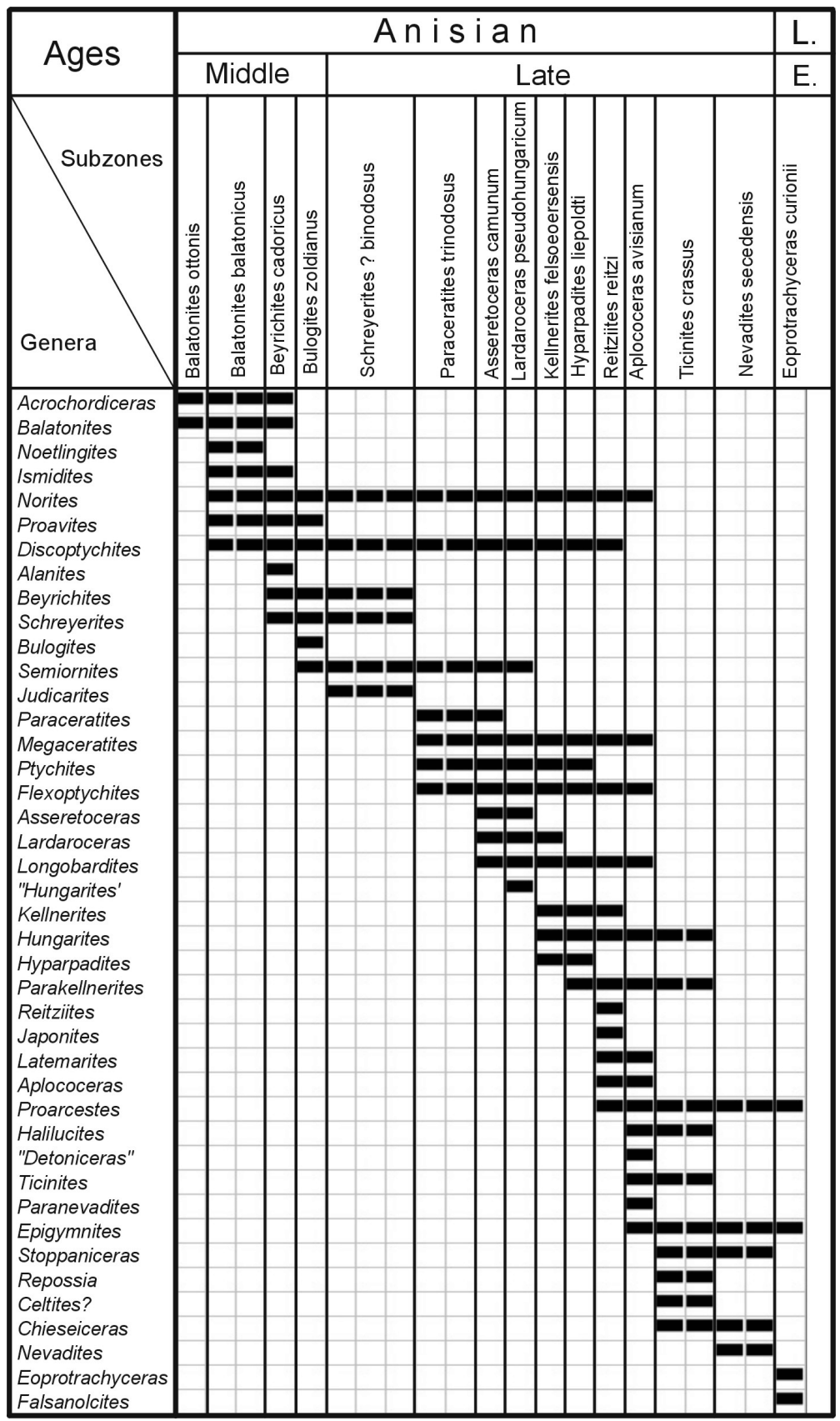

Fig. 3

Range chart of middle Anisian to earliest Ladinian ammonoid genera in the Balaton Highland. L.: Ladinian, E.: early. (Data from Vörös 1998, 2003) 


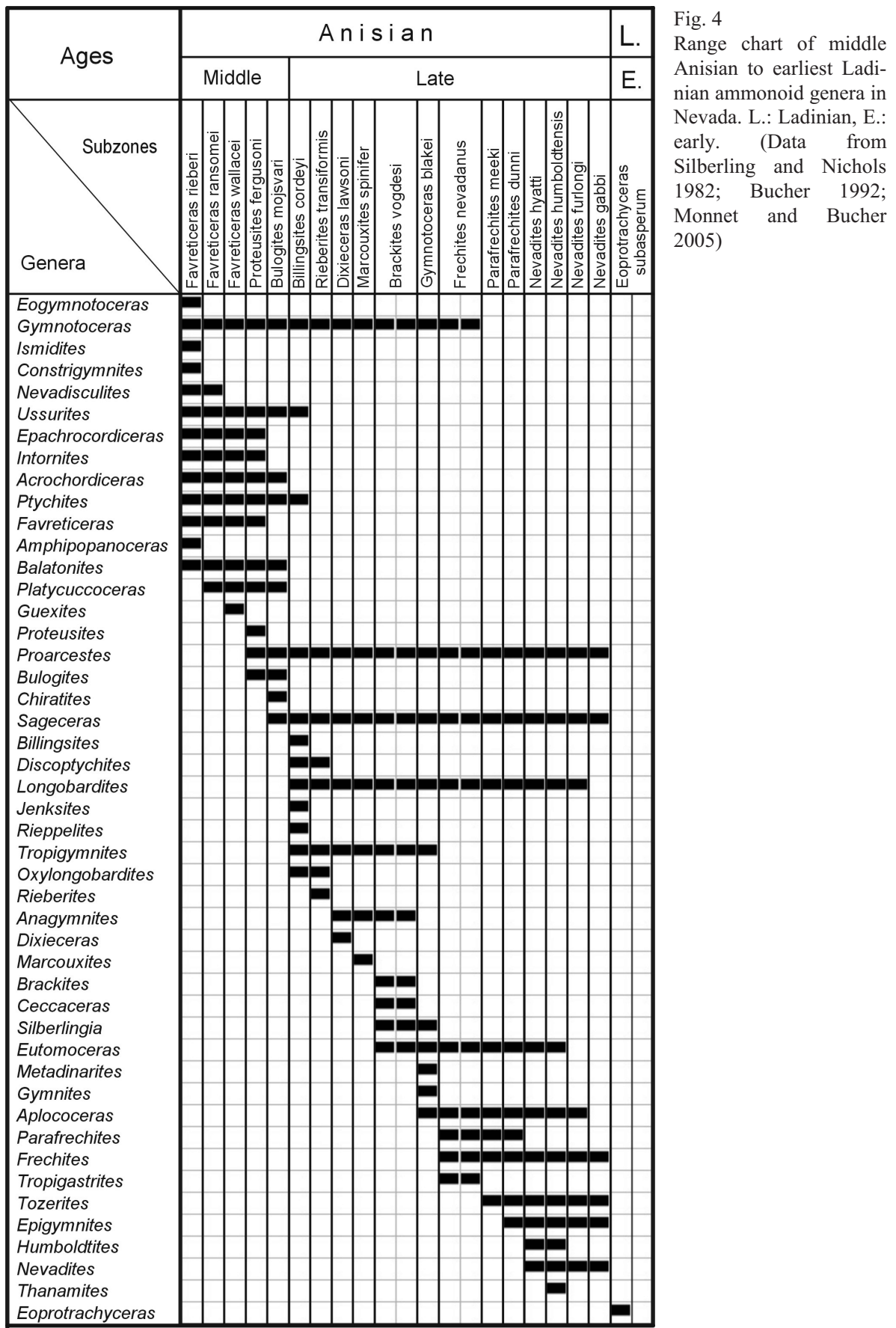

Central European Geology 57, 2014 
Following the method of Brühwiler et al. (2010), turnover is defined here as the sum of originations and extinctions between two subzones. In our case, because of working with local databases, the expressions "first appearances" and "last appearances" are used instead of originations and extinctions, respectively. The percentage of turnover is the turnover divided by the total number of genera occurring in the two bordering subzones.

\section{Results}

The numerical data of simple counts of occurrences of ammonoid genera in the middle Anisian (Pelsonian), late Anisian (Illyrian) and earliest Ladinian are shown in Table 2. The temporal change in the total number of genera recorded in the three study areas (middle Anisian: 30, late Anisian: 67, earliest Ladinian: 5) shows a more than twofold increase during the Anisian, and fits the global diversity curve rather well (Fig. 1) (it must be mentioned that the earliest Ladinian minimum may be an artifact; this interval is represented by scarce faunas of only single subzones in all three areas studied). Clearly the middle to late Anisian diversity increase was much more marked in the western Tethyan (Alpine) areas than in Nevada (Table 2).

Table 2

Number of ammonoid genera by ages in the three study areas and altogether

\begin{tabular}{lcccc}
\hline & Eastern Lombardy & Balaton Highland & Nevada & Three areas altogether \\
\hline Early Ladinian & 3 & 4 & 1 & 5 \\
Late Anisian & 46 & 33 & 31 & 68 \\
Middle Anisian & 7 & 12 & 20 & 30 \\
\hline
\end{tabular}

The middle to late Anisian ammonoid diversification can be further analyzed by counting the occurrences in narrower time intervals. In this case the advanced stratigraphic subdivisions (at the subzonal level) developed at the three studied areas allow expressing the temporal changes in generic richness in the particular subzones (Tables 3-5). These tables also show some other data on diversity dynamics, such as the originations and extinctions (in fact the first and last appearances) of the ammonoid genera and their turnover rates. The changes in ammonoid generic richness and turnover have been plotted in Figs 5-7.

The late Anisian (late Illyrian) peak in ammonoid diversification is very obvious in the two Alpine areas. In Eastern Lombardy (Table 3, Fig. 5) the number of ammonoid genera is low and slowly increases (from 2 to 6 ) in the middle Anisian, then an extremely high value (22) is seen in the Ticinites crassus Subzone, near the end of the late Anisian, and an abrupt decrease is recorded toward the earliest Ladinian. The turnover is also very high toward the end of the Anisian; proportions of the originations (first appearances) are especially high at the bases of the Aplococeras avisianum and Ticinites crassus Subzones. 
Table 3

Number of ammonoid genera and their first (F. a.) and last appearances (L. a.) and turnover data in separate Anisian subzones in Eastern Lombardy

\begin{tabular}{|c|c|c|c|c|}
\hline \multirow{2}{*}{ Subzones } & \multirow{2}{*}{ Genera } & F. a. & \multirow{2}{*}{ Turnover } & \multirow{2}{*}{ Turnover $\%$} \\
\hline & & L. a. & & \\
\hline \multirow{2}{*}{ Eoprotrachyceras curionii } & \multirow{2}{*}{3} & & & \\
\hline & & 2 & \multirow{2}{*}{14} & \multirow{2}{*}{88} \\
\hline \multirow{2}{*}{ Nevadites secedensis } & \multirow{2}{*}{13} & 12 & & \\
\hline & & 3 & \multirow{2}{*}{15} & \multirow{2}{*}{43} \\
\hline \multirow{2}{*}{ Ticinites crassus } & \multirow{2}{*}{22} & 12 & & \\
\hline & & 9 & \multirow{2}{*}{12} & \multirow{2}{*}{32} \\
\hline \multirow{2}{*}{ Aplococeras avisianum } & \multirow{2}{*}{16} & 3 & & \\
\hline & & 9 & \multirow{2}{*}{14} & \multirow{2}{*}{50} \\
\hline \multirow{2}{*}{ Reitziites reitzi } & \multirow{2}{*}{12} & 5 & & \\
\hline & & 3 & \multirow{2}{*}{3} & \multirow{2}{*}{16} \\
\hline \multirow{2}{*}{ Hyparpadites bagolinensis } & \multirow{2}{*}{9} & 0 & & \\
\hline & & 2 & \multirow{2}{*}{3} & \multirow{2}{*}{20} \\
\hline \multirow{2}{*}{ "Kellnerites" } & 8 & 1 & & \\
\hline & 8 & 2 & 2 & 23 \\
\hline "I ardaroceras" & 7 & 1 & 3 & 25 \\
\hline Lardaroceras & 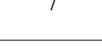 & 1 & 3 & 23 \\
\hline "A sceretoceras" & 8 & 2 & 3 & 25 \\
\hline & & 3 & $\varepsilon$ & 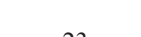 \\
\hline & & 2 & 5 & 23 \\
\hline Paracerantes trmodosus & 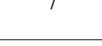 & 3 & 5 & 38 \\
\hline Schreverites abichi & 6 & 2 & J & 50 \\
\hline Schreyerites abich1 & 6 & 3 & 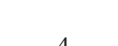 & 10 \\
\hline Jdioritos our omo & 4 & 1 & 4 & 40 \\
\hline 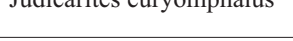 & 4 & 1 & 4 & 40 \\
\hline Riennelites cimeganus & 6 & 3 & 4 & 40 \\
\hline & & 3 & 6 & 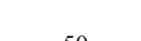 \\
\hline Puloritos zoldianu & 6 & 3 & 6 & 50 \\
\hline Burogites Zororanus & 0 & 3 & 3 & 33 \\
\hline Rolotonites bolotonicin & 3 & 0 & 3 & 33 \\
\hline Balatonites balatonicus & 3 & 2 & 2 & 60 \\
\hline Balatonites ottonis & 2 & 1 & J & 00 \\
\hline & & & & \\
\hline
\end{tabular}




\begin{tabular}{|c|c|c|c|}
\hline & Subzones & Turnover & Generic richness \\
\hline E. L. & Eoprotrachyceras curionii & & \\
\hline \multirow{12}{*}{$\begin{array}{l}\text { Late } \\
\text { Anisian }\end{array}$} & Nevadites secedensis & & \\
\hline & Ticinites crassus & & \\
\hline & Aplococeras avisianum & & \\
\hline & Reitziites reitzi & & \\
\hline & Hyparpadites bagolinensis & & \\
\hline & "Kellnerites" & & \\
\hline & "Lardaroceras" & & \\
\hline & "Asseretoceras" & & $\boldsymbol{\Sigma}$ \\
\hline & Paraceratites trinodosus & & \\
\hline & Schreyerites abichi & & \\
\hline & Judicarites euryomphalus & & \\
\hline & Rieppelites cimeganus & & \\
\hline \multirow{3}{*}{$\begin{array}{l}\text { Middle } \\
\text { Anisian }\end{array}$} & Bulogites zoldianus & & \\
\hline & Balatonites balatonicus & & \\
\hline & Balatonites ottonis & $50 \%$ & \\
\hline
\end{tabular}

Fig. 5

Generic richness and turnover of middle Anisian to earliest Ladinian ammonoids in Eastern Lombardy. Values (bars) and percentages (shaded areas) of turnover of genera. E. L.: early Ladinian

The temporal changes in ammonoid diversity are rather similar in the Balaton Highland as well (Table 4, Fig. 6), with the differences that there is a higher middle Anisian peak (9) in the Beyrichites cadoricus Subzone, and that the late Anisian maximum (14) is somewhat smaller and appears a little earlier (Aplococeras avisianum Subzone) than in Eastern Lombardy. The turnover values follow similar trends, with latest Anisian maxima, except for a peak at the base of the Paraceratites trinodosus Subzone. The numbers of originations (first appearances) mostly correspond to the mentioned maxima of the turnover values.

In Nevada (Table 5, Fig. 7) the generic richness values show much less temporal variation, and almost no trends. The middle Anisian starts with a low maximum in the Favreticeras rieberi Subzone (13 genera); then the number of genera fluctuates between 6 and 12, and three smaller peaks can be recorded in the Proteusites fergusoni, the Billingsites cordeyi, and the latest Anisian Nevadites humboldtensis Subzones, respectively. The turnover maximum is reached in the Billingsites cordeyi Subzone; here the proportion of the originations is also high. The turnover remains rather low throughout the late Anisian. At the latest Anisian maximum of generic richness (Nevadites humboldtensis and adjacent Subzones) the turnover and especially the number of originations is extremely low. 
Table 4

Number of ammonoid genera and their first (F. a.) and last appearances (L. a.) and turnover data in separate Anisian subzones at the Balaton Highland

\begin{tabular}{|c|c|c|c|c|}
\hline \multirow{2}{*}{ Subzones } & \multirow{2}{*}{ Genera } & F. a. & \multirow{2}{*}{ Turnover } & \multirow{2}{*}{ Turnover $\%$} \\
\hline & & L. a. & & \\
\hline \multirow{2}{*}{ Eoprotrachyceras curionii } & \multirow{2}{*}{4} & & & \\
\hline & & 2 & \multirow{2}{*}{5} & \multirow{2}{*}{55} \\
\hline \multirow{2}{*}{ Nevadites secedensis } & \multirow{2}{*}{5} & 3 & & \\
\hline & & 1 & \multirow{2}{*}{7} & \multirow{2}{*}{47} \\
\hline \multirow{2}{*}{ Ticinites crassus } & \multirow{2}{*}{10} & 6 & & \\
\hline & & 4 & \multirow{2}{*}{12} & \multirow{2}{*}{50} \\
\hline \multirow{2}{*}{ Aplococeras avisianum } & \multirow{2}{*}{14} & 8 & & \\
\hline & & 5 & \multirow{2}{*}{9} & \multirow{2}{*}{33} \\
\hline \multirow{2}{*}{ Reitziites reitzi } & \multirow{2}{*}{13} & 4 & & \\
\hline & & 5 & \multirow{2}{*}{7} & \multirow{2}{*}{30} \\
\hline \multirow{2}{*}{ Hyparpadites liepoldti } & \multirow{2}{*}{10} & 2 & & \\
\hline & & 1 & \multirow{2}{*}{2} & \multirow{2}{*}{10} \\
\hline \multirow{2}{*}{ Kellnerites felsoeoersensis } & \multirow{2}{*}{10} & 1 & & \\
\hline & & 3 & 6 & 30 \\
\hline 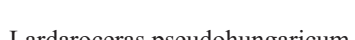 & 10 & 3 & 0 & \\
\hline Lardaroceras pseuconungaricum & 10 & 1 & 2 & 10 \\
\hline Asseretoceras camunum & 10 & 1 & 2 & 10 \\
\hline & & 3 & 3 & 18 \\
\hline Parnceratites trinodocus & 7 & 0 & J & 10 \\
\hline Paraceratites trinocosus & 1 & 4 & 7 & 54 \\
\hline Schreverites? binodosus & 6 & 3 & I & 34 \\
\hline & & 1 & 3 & 23 \\
\hline Pulogites zoldianus & 7 & 2 & & \\
\hline Duiogites Zordiantus & 1 & 2 & 6 & 38 \\
\hline Beyrichites cadoricus & 9 & 4 & 0 & 30 \\
\hline Beyrichites cadoricus & 9 & 3 & 4 & 25 \\
\hline Balatonites balatonicus & 7 & 1 & 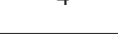 & 20 \\
\hline & & 5 & 5 & 56 \\
\hline Balatonites ottonis & 2 & 0 & & \\
\hline & & & & \\
\hline
\end{tabular}

For an easier and direct comparison, the generic richness curves of Eastern Lombardy, Balaton Highland and Nevada are shown in Fig. 8. In the Middle Triassic the diversity increases in the two Tethyan areas, while it is steadily and moderately high in Nevada. The marked diversity peaks appear near the end of the late Anisian in Eastern Lombardy and a little earlier in the Balaton area; a much less pronounced latest Anisian diversity peak is seen in Nevada. 


\begin{tabular}{|c|c|c|c|}
\hline & Subzones & Turnover & Generic richness \\
\hline E. L. & Eoprotrachyceras curionii & & \\
\hline \multirow{10}{*}{$\begin{array}{l}\text { Late } \\
\text { Anisian }\end{array}$} & Nevadites secedensis & & \\
\hline & Ticinites crassus & & \\
\hline & Aplococeras avisianum & & \\
\hline & Reitziites reitzi & & \\
\hline & Hyparpadites liepoldti & & \\
\hline & Kellnerites felsoeoersensis & & \\
\hline & Lardaroceras pseudohungaricum & & \\
\hline & Asseretoceras camunum & & \\
\hline & Paraceratites trinodosus & & \\
\hline & Schreyerites? binodosus & & \\
\hline \multirow{4}{*}{$\begin{array}{l}\text { Middle } \\
\text { Anisian }\end{array}$} & Bulogites zoldianus & & \\
\hline & Beyrichites cadoricus & & \\
\hline & Balatonites balatonicus & & \\
\hline & Balatonites ottonis & $100 \%$ & \\
\hline
\end{tabular}

Fig. 6

Generic richness and turnover of middle Anisian to earliest Ladinian ammonoids in the Balaton Highland. Values (bars) and percentages (shaded areas) of turnover of genera. E. L.: early Ladinian

\section{Discussion}

The Middle Triassic temporal changes in generic richness and turnover rates of ammonoid genera presented above suggest two pulses of diversification: one in the middle Anisian (Pelsonian) and another, more prominent, near the end of the late Anisian (late Illyrian).

\section{The Pelsonian global diversification}

The first phase of ammonoid diversification in the Pelsonian (i.e. in the Balatonites balatonicus/shoshonensis Zones) seems to be a global phenomenon. It can be recorded in the western Tethyan areas and in Nevada as well, and is characterized by the common occurrence of the genera Balatonites, Acrochordiceras, Bulogites and Ismidites, beside the cosmopolitan Ptychites and Proarcestes. Moreover, diverse ammonoid faunas of this age and partly similar composition were reported from several low-latitude localities, e.g. Turkey (Fantini Sestini 1988), Israel (Parnes 1986), the Himalayas (Krystyn et al. 2004), Tibet (Gu et al. 1980) and Southwest China (Stiller and Bucher 2008). The geographical distribution of the genus Balatonites is even wider, including Thailand (Kummel 1960), Vietnam (Khuc 2000) and Japan (Bando 1964). This almost worldwide distribution implies a rapid and effective migration episode of ammonoids 
Table 5

Number of ammonoid genera and their first (F. a.) and last appearances (L. a.) and turnover data in separate Anisian subzones in Nevada

\begin{tabular}{|c|c|c|c|c|}
\hline \multirow{2}{*}{ Subzones } & \multirow{2}{*}{ Genera } & F. a. & \multirow{2}{*}{ Turnover } & \multirow{2}{*}{ Turnover $\%$} \\
\hline & & L. a. & & \\
\hline \multirow{2}{*}{ Eoprotrachyceras subasperum } & \multirow{2}{*}{1} & & & \\
\hline & & 1 & \multirow{2}{*}{7} & \multirow{2}{*}{100} \\
\hline \multirow{2}{*}{ Nevadites gabbi } & \multirow{2}{*}{6} & 6 & & \\
\hline & & 0 & \multirow{2}{*}{2} & \multirow{2}{*}{14} \\
\hline \multirow{2}{*}{ Nevadites furlongi } & \multirow{2}{*}{8} & 2 & & \\
\hline & & 0 & \multirow{2}{*}{3} & \multirow{2}{*}{16} \\
\hline \multirow{2}{*}{ Nevadites humboldtensis } & \multirow{2}{*}{11} & 3 & & \\
\hline & & 1 & \multirow{2}{*}{1} & \multirow{2}{*}{1} \\
\hline \multirow{2}{*}{ Nevadites hyatti } & \multirow{2}{*}{10} & 0 & & \\
\hline & & 2 & \multirow{2}{*}{3} & \multirow{2}{*}{16} \\
\hline \multirow{2}{*}{ Parafrechites dunni } & \multirow{2}{*}{9} & 1 & & \\
\hline & & 1 & 1 & 1 \\
\hline Parafrechites meeki & 8 & 0 & 1 & 1 \\
\hline 1 (19) & & 1 & 3 & 18 \\
\hline Frechites nevadanus & 0 & 2 & 3 & 10 \\
\hline 1 & (3) & 3 & 7 & 37 \\
\hline Gumnetoreres blakei & 10 & 4 & & \\
\hline 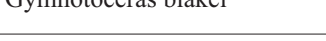 & 10 & 3 & 6 & 20 \\
\hline Rrockites yordeci & 10 & 3 & 0 & 29 \\
\hline Brackites vogdes1 & 10 & 4 & 5 & 29 \\
\hline Marcouxites spinifer & 7 & 1 & & \\
\hline 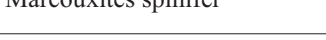 & 1 & 1 & 2 & 14 \\
\hline Dixieceras lawsoni & 7 & 1 & & \\
\hline Dixteceras lawsoin & 1 & 2 & 5 & 33 \\
\hline Rieberites transiformis & 8 & 3 & & \\
\hline 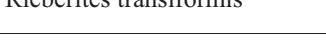 & 0 & 1 & 6 & 30 \\
\hline Billingsites cordevi & 12 & 5 & & \\
\hline & & 7 & 12 & 55 \\
\hline Bulogites moisyari & 10 & 5 & 12 & \\
\hline & & 2 & 6 & 27 \\
\hline Proteucites forouni & 12 & 4 & 0 & 21 \\
\hline 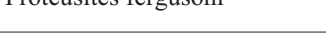 & 12 & 3 & 4 & 18 \\
\hline Favreticeras wallacei & 10 & 1 & 4 & 18 \\
\hline Haveticetias wallacer & 10 & 1 & 2 & 10 \\
\hline Fayreticeras ransomei & 10 & 1 & 2 & \\
\hline Favieticeras ransonter & 10 & 1 & 5 & 22 \\
\hline Favreticeras rieberi & 13 & 4 & & \\
\hline & & & & \\
\hline
\end{tabular}




\begin{tabular}{|c|c|c|c|}
\hline & Subzones & Turnover & $\underset{10}{\text { Generic richness }}$ \\
\hline E. L. & Eoprotrachyceras subasperum & & \\
\hline \multirow{13}{*}{$\begin{array}{c}\text { Late } \\
\text { Anisian }\end{array}$} & Nevadites gabbi & & \\
\hline & Nevadites furlongi & & \\
\hline & Nevadites humboldtensis & & \\
\hline & Nevadites hyatti & & \\
\hline & Parafrechites dunni & & \\
\hline & Parafrechites meeki & & \\
\hline & Frechites nevadanus & & \\
\hline & Gymnotoceras blakei & & \\
\hline & Brackites vogdesi & & \\
\hline & Marcouxites spinifer & & \\
\hline & Dixieceras lawsoni & & \\
\hline & Rieberites transiformis & & \\
\hline & Billingsites cordeyi & & \\
\hline \multirow{5}{*}{$\begin{array}{l}\text { Middle } \\
\text { Anisian }\end{array}$} & Bulogites mojsvari & & \\
\hline & Proteusites fergusoni & & \\
\hline & Favreticeras wallacei & & \\
\hline & Favreticeras ransomei & & \\
\hline & Favreticeras rieberi & 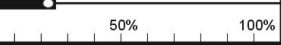 & \\
\hline
\end{tabular}

Fig. 7

Generic richness and turnover of middle Anisian to earliest Ladinian ammonoids in Nevada. Values (bars) and percentages (shaded areas) of turnover of genera. E. L.: early Ladinian

along the low latitude belts of the Tethys and Panthalassa oceans. This late middle Anisian (Pelsonian) diversification event and its worldwide appearance may be interpreted as the result of a coeval phase of global sea-level rise (Haq et al. 1988) and the synchronous effect of amplified oceanic circulation. Opening of previously restricted basins might have further increased the taxonomic diversity and the dispersal of ammonoids through the Panthalassa. Flooding of former land areas provided newly available niches and supplied increased amounts of food (organic matter and nutrients), thus fostering the diversity of marine ecosystem.

\section{The early Illyrian diversity drop}

A definite decrease of ammonoid generic richness is recorded both in the diversity curves for both the western Tethys and Nevada (Fig. 8) in the early late Anisian (early Illyrian: Paraceratites trinodosus and Gymnotoceras mimetus Zones, respectively). This corresponds to and may partly be explained by a coeval global sea-level fall (Haq et al. 1988). The diversity minimum coincides with a maximum of endemism: with the exception of Longobardites and the cosmopolitan Proarcestes and Discoptychites, the 
generic composition of the western Tethyan and Nevadan ammonoid faunas is totally different at this time.

Even in the middle Illyrian, ammonoid migration was possible within the Tethys, as documented by the occurrences of the important western Tethyan index genus Reitziites in the Himalayas (Krystyn et al. 2004) and Japan (Bando 1964). On the other hand, the endemism between the western Tethys and Nevada remained rather high through the Anisian, posing difficulties for the ammonoid-based biostratigraphic correlation. Some degree of ammonoid migration can be recorded only near the end of the Anisian, when (beside the mentioned cosmopolitan genera) Aplococeras, Epigymnites and Nevadites appeared both in Nevada and in the western Tethys.

\section{The late Illyrian diversification}

The latest Anisian peak of ammonoid diversity in the Nevada succession (Figs 7, 8) is very low compared to the respective maxima seen in the western Tethyan curves. In general the Nevadan diversity curve is rather flat, with weak fluctuations. This is in accordance with the uniform nature of the local sedimentary environment. The host rock of the celebrated Anisian ammonoids of Nevada, the Fossil Hill Member of the Prida and Favret Formation, consists of fairly uniform strata of alternating silty shale and

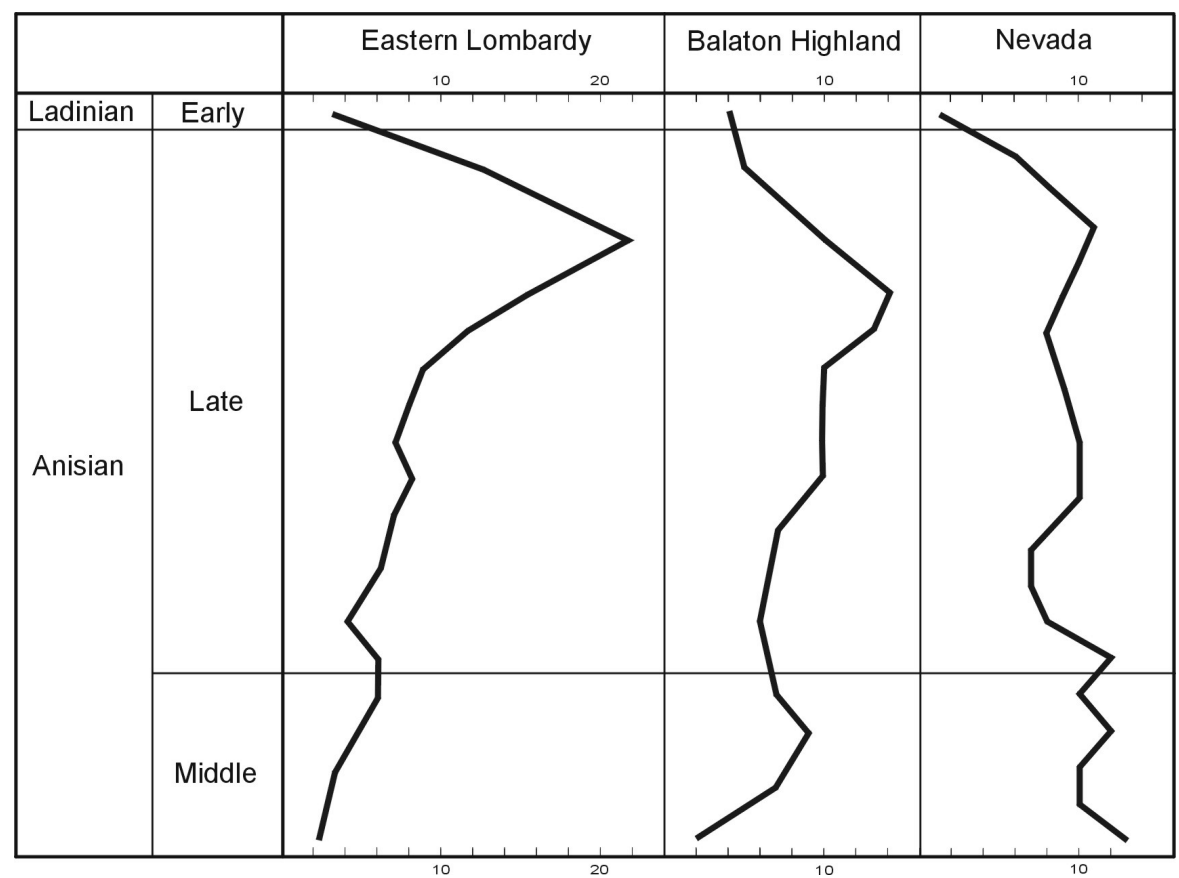

Fig. 8

Ammonoid generic richness curves of the three regions studied 
dark lime mudstone deposited below the storm wave base in an euxinic paleoenvironment (Monnet and Bucher 2005). In a stable environment of this kind signs of any ammonoid diversification events in other parts of the Triassic oceans might appear only in times of enhanced migration through the Panthalassa.

The steady nature of the Nevadan diversity curve and the rather low turnover with mostly small number of originations (Table 5, Fig. 7), indicate a lack of reorganization of communities. This probably reflects not only the stability of the local environmental factors but also the absence of major global changes. The next prominent sea-level rise commenced only in the earliest Ladinian (Haq et al. 1988); the carbon cycle, which strongly fluctuated in the Early Triassic, was stable in the Middle Triassic (Galfetti et al. 2007a; Brühwiler et al. 2010). It is assumed that the standard diversification process in Nevada mirrors a generally low inherent evolutionary rate of the Middle Triassic ammonoids in contrast to the high evolutionary rates in the Early Triassic recorded by Brayard et al. (2009) and Brühwiler et al. (2010).

The explosive late Illyrian diversity peak in the western Tethys

The latest Anisian (late Illyrian) peak in ammonoid diversification is very obvious both in Eastern Lombardy and in the Balaton Highland (Tables 3, 4; Figs 5, 6, 8). Not only the generic richness of ammonoids but also the turnover is very high; furthermore the turnover is due to the high proportion of originations (first appearances) during this time interval. Consequently, this diversity peak indicates a significant reorganization of communities with accumulation of newly originated taxa.

Considering the absence of major global changes and a generally low evolutionary rate of ammonoids in the Middle Triassic, the best possible explanation of the latest Anisian (late Illyrian) explosive diversity peaks recorded in the western Tethyan regions implies significant changes of the regional environmental factors.

From the array of conceivable conditions of a Triassic paleoenvironment possibly affecting ammonoid proliferation, two geologically well-observable factors were selected here: (1) coeval volcanic activity and (2) the growth of carbonate platforms in the surrounding regions. The temporal distribution and magnitude of these geologic phenomena and their apparent relation to ammonoid diversity in Eastern Lombardy and in the Balaton Highland are shown in Figs 9 and 10.

\section{Anisian volcanism}

Volcanic ash layers are frequently interbedded within the pelagic basinal limestone both in Eastern Lombardy and at the Balaton Highland. In Eastern Lombardy these mostly centimeter-thick acidic, airfall ash layers of the lower "pietra verde" are used for long-distance tephrastratigraphic correlation (Mundil et al. 1996; Brack et al. 2005). In the Balaton Highland the individual volcano-sedimentary layers are much thicker (up to 8 meters) and varied in grain size and composition, from bentonitic clay to crystal tuff containing vitro- and lithoclasts, feldspar, biotite and quartz grains (Cros and Szabó 1984; Pálfy et al. 2003). The tight biostratigraphic control both in Eastern 


\begin{tabular}{|c|c|c|c|c|}
\hline & Subzones & Platforms & Volcanism & Ammonoid diversity \\
\hline E. L. & Eoprotrachyceras curionii & & & \\
\hline \multirow{12}{*}{$\begin{array}{c}\text { Late } \\
\text { Anisian }\end{array}$} & Nevadites secedensis & & & \\
\hline & Ticinites crassus & & & \\
\hline & Aplococeras avisianum & 이 & & \\
\hline & Reitziites reitzi & & 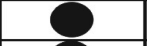 & \\
\hline & Hyparpadites bagolinensis & & & \\
\hline & "Kellnerites" & & & \\
\hline & "Lardaroceras" & & & \\
\hline & "Asseretoceras" & i促 & 0 & \\
\hline & Paraceratites trinodosus & 昼 & & \\
\hline & Schreyerites abichi & & & \\
\hline & Judicarites euryomphalus & & & \\
\hline & Rieppelites cimeganus & & & \\
\hline \multirow{3}{*}{$\begin{array}{l}\text { Middle } \\
\text { Anisian }\end{array}$} & Bulogites zoldianus & & & \\
\hline & Balatonites balatonicus & $\sum^{2}$ & & \\
\hline & Balatonites ottonis & & & \\
\hline
\end{tabular}

Fig. 9

Temporal distribution and magnitude of volcanic activity and growth of carbonate platforms and their relation to ammonoid diversity in Eastern Lombardy. Carbonate platforms of direct effect (solid contour line) and carbonate platforms of indirect/distant effect (dashed contour line). E.L.: early Ladinian, C.D.M.: Camorelli-Dosso dei Morti carbonate platform

Lombardy and in the Balaton Highland proved that the explosive volcanic events commenced synchronously in the two regions (Brack et al. 2005; Vörös et al. 2009) (Figs 9, 10). The first traces (clayey tuff) appeared in the middle Illyrian "Asseretoceras beds"; the frequency and volume of volcanic ash falls culminated in the Reitzi Zone and then considerably decreased in the latest Illyrian.

Volcanism, especially ash fall, is known as important fertilizer of present day oceanic surface waters, either as primary source of nutrients or as a supply of iron, a biologically limiting key element (Watson 1997; Langmann et al. 2010). This fertilization process, which also functioned in the past of the Earth (e.g. Pálfy 2003), highly increased the primary productivity, i.e. the biomass, of the phyto- and zooplankton. For the present study strong evidence of the fertilization model is given by the blooms of planktonic radiolarians in apparent temporal relationship with the late Anisian ash fall events both in Eastern Lombardy (Kozur and Mostler 1994; Ozsvárt 2012 and pers. comm.) and in the Balaton Highland (Dosztály 1993; Ozsvárt 2012 and pers. comm.). It seems reasonable that the middle Anisian increase of ammonoid diversity in the 


\begin{tabular}{|c|c|c|c|c|}
\hline & Subzones & Platforms & Volcanism & Ammonoid diversity \\
\hline E. L. & Eoprotrachyceras curionii & & & \\
\hline \multirow{10}{*}{$\begin{array}{l}\text { Late } \\
\text { Anisian }\end{array}$} & Nevadites secedensis & מִ & & \\
\hline & Ticinites crassus & & & \\
\hline & Aplococeras avisianum & & & \\
\hline & Reitziites reitzi & & & \\
\hline & Hyparpadites liepoldti & & & \\
\hline & Kellnerites felsoeoersensis & 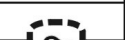 & & \\
\hline & Lardaroceras pseudohungaricum & : & & \\
\hline & Asseretoceras camunum & & 0 & \\
\hline & Paraceratites trinodosus & & & \\
\hline & Schreyerites ? binodosus & & & \\
\hline \multirow{4}{*}{$\begin{array}{l}\text { Middle } \\
\text { Anisian }\end{array}$} & Bulogites zoldianus & & & \\
\hline & Beyrichites cadoricus & & & \\
\hline & Balatonites balatonicus & $\frac{1}{6}$ & & \\
\hline & Balatonites ottonis & $巨$ & & \\
\hline
\end{tabular}

Fig. 10

Temporal distribution and magnitude of volcanic activity and growth of carbonate platforms and their relation to ammonoid diversity in the Balaton Highland. Carbonate platforms of direct effect (solid contour line) and carbonate platforms of indirect/distant effect (dashed contour line). E.L.: early Ladinian, P.?: Piramita carbonate platform

western Tethyan regions can also partly be interpreted in terms of increasing food supply due to fertilization by ash fall episodes of regional volcanism.

Apart from the explosive volcanism, other volcanic sources of fertilization can be considered, such as submarine volcanism and hydrothermal activity along mid-oceanic volcanic ridges. The Middle Triassic was a time of accelerated spreading in the western Tethyan oceanic basins (Stampfli and Borel 2002; Csontos and Vörös 2004) but the relative palaeogeographic position of the Southern Alps and the Balaton Highland to these ocean basins is much debated. Therefore the role of this alternative source of nutrients is not discussed further in the present paper.

Anisian carbonate platforms

Carbonate platforms as biologically constructed shallow marine buildups disappeared at the end-Permian biotic catastrophe and slowly began to develop again in the Middle Triassic, first in the early Anisian in the eastern (Southwest China: Payne et al. 2006), then in the middle Anisian, in the western Tethys (Senowbari-Daryan et al. 1993; Russo 2005; Velledits et al. 2011). The carbonate platforms, as novel elements of the Mesozoic marine environment after the "reef gap" (Senowbari-Daryan et al. 
1993), significantly contributed to the global evolution of marine biota. The stabilization of platform-margin sediments by algae and associated microbial mats produced submarine escarpments with a hard substrate and offered various habitats, from the shallow to deep subtidal or even bathyal zones. This habitat diversification opened new niches for the benthos but also for the nektonic ammonoids. Besides, the microbial biofilms and other organisms of the carbonate platform biotic community, as primary producers, presumably supplied additional suspended organic matter and eventually nutrients for the higher trophic levels of the food chain. Moreover, the slopes of the carbonate platforms, steeply emerging from the surrounding basins, may have driven upwelling currents carrying nutrients. Field observations and statistical studies proved that certain Anisian ammonoids lived preferentially near the platform margins and their shells were accumulated in the platform interiors or were swept to the surrounding deeper basins (Brack and Rieber 1993; Vörös 2002).

The late Illyrian ammonoids of Eastern Lombardy and the Balaton Highland, used for the database of the present study, have been collected principally from pure micritic or cherty, nodular or well-bedded limestone of pelagic basinal facies (Vörös 1998, 2003; Brack et al. 2005). However, during most of the late Anisian, these deeper basins were surrounded by fast-growing carbonate platforms (Budai and Vörös 2006; Brack et al. 2007; Monnet et al. 2008) and the fossil ammonoid assemblages probably reflect the composition of different communities once living in different habitats. In Eastern Lombardy, the early Pelsonian Dosso dei Morti carbonate platform (Monnet et al. 2008) can be encountered as possibly contributing to the Pelsonian diversity increase. The Esino Platform developed farther to the west in Lombardy (e.g. Val Parina) and later (mostly in the Ladinian). Its continuous ammonoid record starts only in the Secedensis Zone and falls mostly within the Curionii to Archelaus Zones (Fantini Sestini 1994, 1996). As for the Illyrian diversity peak, the distant, indirect paleobiological effects of two successive carbonate platforms can be considered: the Contrin Platform (early Illyrian) and the Latemar/Sciliar Platform (late Illyrian) (Fig. 9). Both platforms attained their full development in the Dolomites, to the east of Lombardy (Brack et al. 2007), but the signs of their progradation into the Lombardian basin was demonstrated by Brack and Rieber (1993). The ammonoid fauna of the Latemar Platform is especially diverse, as portrayed by Brack and Rieber (1993) and Manfrin et al. (2005).

In the Balaton Highland the Tagyon Platform was growing in the Pelsonian, and the Budaörs Platform existed in the late Illyrian and prograded toward the basins in the latest Anisian (Budai and Vörös 2006). The short-lived, local Piramita Platform (or platform tongue) developed in the intervening middle Illyrian time in the Eastern Bakony (Budai et al. 2001). Just as in the case of Eastern Lombardy, the temporal relationship between platform growth and ammonoid diversity is well-established in the Balaton Highland (Fig. 10).

This relationship can be interpreted in terms of habitat diversification by opening new niches. It is supported by the fact that many of the genera which originated during 
the late Anisian Reitzi Zone (Hungarites, Parakellnerites, Aplococeras, Latemarites) were claimed to be ecologically connected to the platform or peri-platform environments (Brack and Rieber 1993; Vörös 2002). It seems that this remarkable diversity peak was due to high turnover rates and increasing number of newly originated ammonoid genera, and that this evolutionary burst was driven by the large-scale, at least Tethys-wide environmental change: the rejuvenated growth of carbonate platforms. In other words this major diversity peak can be regarded as a manifestation of the co-evolution of the Tethyan carbonate platforms and the ammonoids in the Middle Triassic.

\section{Conclusions}

The temporal changes in generic richness and turnover rates of Middle Triassic ammonoid genera show two pulses of diversification: one in the middle Anisian (Pelsonian) and another, more prominent one, near the end of the late Anisian (late Illyrian)

The Pelsonian global diversification was connected to global sea-level rise and a rapid migration episode of many ammonoid genera (Balatonites, Acrochordiceras, Bulogites, Ismidites, Ptychites and Proarcestes) along the low-latitude belts of the Tethys and Panthalassa oceans. Opening of previously restricted basins and flooding of former land areas increased the number of vacant niches and the amount of organic matter and nutrients for the food chain of the marine ecosystem.

In the early Late Anisian (Early Illyrian) the ammonoid generic richness decreased both in the western Tethys and in Nevada. The diversity minimum coincides with strong endemism in both the western Tethys and Nevada.

The latest Anisian (Late Illyrian) global peak of ammonoid diversity shows marked spatial differences. For the Nevadan ammonoid succession this relatively low peak and the rather steady Anisian diversity curve can be explained by the uniform nature of the local sedimentary environment and is supported by low inherent rates of ammonoid evolution (low turnover, few originations).

Despite the absence of major global changes (e.g. stabilization of the carbon cycle) the Late Illyrian diversity peak is very prominent in the western Tethys: beside the peak in ammonoid generic richness, the turnover is also very high, with high proportion of originations. This prominent peak is interpreted in terms of major changes of two regional environmental factors: coeval volcanic activity and the control of nearby carbonate platforms.

The frequency and volume of volcanic ash falls culminating in the Late Illyrian may have provoked the dramatic increase of ammonoid generic richness by fertilization, i.e. supplying nutrients and/or iron, thus increasing the primary productivity in the pelagic environment.

Carbonate platforms, as novel elements of the Tethyan marine environment re-appearing after the end-Permian crisis in the Anisian, significantly promoted the diversi- 
fication of marine biota, including ammonoids. The platform margins enhanced habitat diversification with newly available niches, whereas the microbial mats and algae, as primary producers, supplied suspended organic matter for the higher trophic levels and eventually the ammonoids.

The deeper basins of the western Tethys were surrounded by fast growing carbonate platforms in the late Anisian and the fossil assemblages probably reflect the compositions of different ammonoid communities once living in different habitats.

In the western Tethyan regions platform growth significantly increased in the late Illyrian and was strictly followed by the remarkable increase of ammonoid generic richness. Many of the genera, originated during the late Anisian Reitzi Zone (Hungarites, Parakellnerites, Aplococeras, Latemarites), seem to be ecologically connected to the platform or peri-platform environments. It is supposed that this prominent diversity peak is a manifestation of the co-evolution of the Tethyan carbonate platforms and the ammonoids.

\section{Acknowledgements}

Thanks are due to J. Pálfy for valuable advices and for reading the first draft. The useful comments and corrections of the reviewers M. Balini and T. Budai which led to an improved manuscript are acknowledged. The research was supported by the grant K 81298 of the Hungarian Scientific Research Fund (OTKA). This is Hungarian Academy of Sciences-Hungarian Natural History Museum-Eötvös Loránd University Paleo Contribution No. 205.

\section{References}

Arkell, W.J., B. Kummel, C.W. Wright 1957: Mesozoic Ammonoidea. - In: Moore, R. (Ed.): Treatise on Invertebrate Paleontology, Part L Mollusca 4. Geological Society of America and University of Kansas Press, pp. L80-L490.

Balini, M. 1992a: New genera of Anisian ammonoids from the Prezzo Limestone (Southern Alps). - Atti Ticinensi di Scienze della Terra, 35, pp. 179-198.

Balini, M. 1992b: Lardaroceras gen. n., a new Late Anisian ammonoid genus from the Prezzo Limestone (Southern Alps). - Rivista Italiana di Paleontologia e Stratigrafia, 98, pp. 3-28.

Balini, M. 1993: Preliminary report on the Pelsonian ammonoids from the Dont section (Eastern Dolomites). - Rivista Italiana di Paleontologia e Stratigrafia, 99(2), pp. 263-270.

Balini, M. 1998: Taxonomy, stratigraphy and phylogeny of the new genus Lanceoptychites (Ammonoidea, Anisian). - Rivista Italiana di Paleontologia e Stratigrafia, 104(2), pp. 143-166.

Balini, M., S.G. Lucas, J.F. Jenks, J.A. Spielmann 2010: Triassic ammonoid biostratigraphy: An overview. - In: Lucas, S.G. (Ed.): The Triassic Timescale. Geological Society, London, Special Publications, 334, pp. 221-262.

Bando, Y. 1964: The Triassic stratigraphy and ammonite fauna of Japan. - Science Reports of the Tohoku University, Sendai, Second Series (Geology), 36(1), pp. 1-137.

Brack, P., H. Rieber 1993: Towards a better definition of the Anisian/Ladinian boundary: New biostratigraphic data and correlations of boundary sections from the Southern Alps. - Eclogae Geologicae Helvetiae, 86(2), pp. 415-527. 
Brack, P., H. Rieber, M. Urlichs 1999: Pelagic successions in the Southern Alps and their correlation with the Germanic Middle Triassic. - Zentralblatt für Geologie und Paläontologie, Teil I, 1998(7-8), pp. 853-876.

Brack, P., H. Rieber, A. Nicora, R. Mundil 2005: The Global boundary Stratigraphic Section and Point (GSSP) of the Ladinian Stage (Middle Triassic) at Bagolino (Southern Alps, Northern Italy) and its implications for the Triassic time scale. - Episodes, 28(4), pp. 233-244.

Brack, P., H. Rieber, R. Mundil, W. Blendinger, F. Maurer 2007: Geometry and chronology of growth and drowning of Middle Triassic carbonate platforms (Cernera and Bivera/Clapsavon) in the Southern Alps (northern Italy). - Swiss Journal of Geosciences, 100, pp. 327-347.

Brayard, A., H. Bucher, G. Escarguel, F. Fluteau, S. Bourquin, T. Galfetti 2006: The Early Triassic ammonoid recovery: Paleoclimatic significance of diversity gradients. - Palaeogeography, Palaeoclimatology, Palaeoecology, 239, pp. 374-395.

Brayard, A., G. Escarguel, H. Bucher, C. Monnet, T. Brühwiler, N. Goudemand, T. Galfetti, J. Guex 2009: Good genes and good luck: Ammonoid diversity and the end-Permian mass extinction. - Science, 325, pp. 1118-1121 (+ supporting online material).

Brühwiler, T., H. Bucher, A. Brayard, N. Goudemand 2010: High-resolution biochronology and diversity dynamics of the Early Triassic ammonoid recovery: The Smithian faunas of the Northern Indian Margin. - Palaeogeography, Palaeoclimatology, Palaeoecology, 297, pp. 491-501.

Bucher, H. 1992: Ammonoids of the Shoshonensis Zone (Middle Anisian, Middle Triassic) from northwestern Nevada (USA). - Jahrbuch der Geologischen Bundesanstalt, 135(2), pp. 425-465.

Budai, T., G. Csillag, A. Vörös, Gy. Lelkes 2001: Középső- és késő-triász platform- és medencefáciesek a Keleti-Bakonyban. (Middle to Late Triassic platform and basin facies of the Eastern Bakony Mts. [Transdanubian Range, Hungary]). - Földtani Közlöny, 130(1-2), pp. 71-95.

Budai, T., A. Vörös 2006: Middle Triassic platform and basin evolution of the southern Bakony Mountains (Transdanubian Range, Hungary). - Rivista Italiana di Paleontologia e Stratigrafia, 112(3), pp. 359-371.

Cros, P., I. Szabó 1984: Comparison of the Triassic volcanogenic formations in Hungary and in the Alps. Paleogeographic criteria. - Acta Geologica Hungarica, 27, pp. 265-276.

Csontos, L., A. Vörös 2004: Mesozoic plate tectonic reconstruction of the Carpathian region. - Palaeogeography, Palaeoclimatology, Palaeoecology, 210, pp. 1-56.

Dagys, A. 2001: The ammonoid family Arctohungaritidae from the Boreal Lower-Middle Anisian (Triassic) of Arctic Asia. - Revue de Paléobiologie, 20(2), pp. 543-641.

Dosztály, L. 1993: The Anisian/Ladinian and Ladinian/Carnian boundaries in the Balaton Highland based on Radiolarians. - Acta Geologica Hungarica, 36(1), pp. 59-72.

Fantini Sestini, N. 1988: Anisian ammonites from Gebze area (Kokaeli Peninsula, Turkey). - Rivista Italiana di Paleontologia e Stratigrafia, 94(1), pp. 35-80.

Fantini Sestini, N. 1994: The Ladinian ammonoids from Calcare di Esino of Val Parina (Bergamasc Alps, Northern Italy). Pt. 1. - Rivista Italiana di Paleontologia e Stratigrafia, 100(2), pp. 227-284.

Fantini Sestini, N. 1996: The Ladinian ammonoids from the Calcare di Esino of Val Parina (Bergamasc Alps, Northern Italy). Pt. 2. - Rivista Italiana di Paleontologia e Stratigrafia, 102(2), pp. 211-226.

Galfetti,T., H. Bucher, A. Brayard, P.A. Hochuli, H. Weissert, K. Guodun, V. Atudorei, J. Guex 2007a: Late Early Triassic climate change: Insights from carbonate carbon isotopes, sedimentary evolution and ammonoid paleobiogeography. - Palaeogeography, Palaeoclimatology, Palaeoecology, 243, pp. 394-412.

Galfetti, T., P.A. Hochuli, A. Brayard, H. Bucher, H. Weissert, J.O. Vigran 2007b: Smithian-Spathian boundary event: Evidence for global climatic change in the wake of the end-Permian biotic crisis. Geology, 35(4), pp. 291-294.

Gu, Qing-ge, Guo-xiong He, Yi-gang Wang 1980: Discovery of the Late Anisian Paraceratites trinodosus fauna (Ammonoidea) from Doilungdeqen, Tibet and its significance. - Acta Palaeontologica Sinica, 19(5), pp. 343-356.

Haq, B.U., J. Hardenbol, P.R. Vail 1988: Mesozoic and Cenozoic chronostratigraphy and cycles of sea-level change. - In: Wilgus, C.K., B.S. Hastings, C.A. Ross, H. Posamentier, J. Van Wagoner, C.G.S.C. Kendall (Eds): Sea-level changes; An integrated approach. SEPM Spec. Publ. 42, pp. $72-108$. 
House, M.R. (1988): Extinction and survival in the Cephalopoda. - In: Larwood, G.P. (ed.): Extinction and Survival in the Fossil Record. Systematics Association. Special Volume 34. Clarendon Press, Oxford, pp. 139-154.

Khuc, Vu, 2000: The Triassic of Indochina Peninsula and its interregional correlation. - In: Hongfu Yin, J.M. Dickins, G.R. Shi, Jinnan Tong (Eds): Permian-Triassic Evolution of Tethys and Western Circum-Pacific. Elsevier, pp. 221-233.

Kozur, H., H. Mostler 1994: Anisian to Middle Carnian radiolarian zonation and description of some stratigraphically important radiolarians. - Geologisch-Paläontologische Mitteilungen Innsbruck, Sonderband, 3, pp. 39-255.

Krystyn, L., M. Balini, A. Nicora 2004: Lower and Middle Triassic stage boundaries in Spiti. Albertiana, 30, pp. 40-53.

Kummel, B. 1960: Triassic ammonoids from Thailand. - Journal of Paleontology, 34(4), pp. 682-694.

Langmann, B., K. Zakšek, M. Hort, S. Duggen 2010: Volcanic ash as fertiliser for the surface ocean. Atmospheric Chemistry and Physics, 10, pp. 3891-3899.

Manfrin, S., P. Mietto, N. Preto 2005: Ammonoid biostratigraphy of the Middle Triassic Latemar platform (Dolomites, Italy) and its correlation with Nevada and Canada. - Geobios, 38, pp. 477-504.

Mietto, P., S. Manfrin 1995: A high resolution Middle Triassic ammonoid standard scale in the Tethys Realm. A preliminary report. - Bulletin de la Société géologique de France, 166(5), pp. 539-563.

Mietto, P., P. Gianolla, S. Manfrin, N. Preto 2003: Refined ammonoid biochronostratigraphy of the Bagolino section (Lombardian Alps, Italy), GSSP candidate for the base of the Ladinian Stage. Rivista Italiana di Paleontologia e Stratigrafia, 109(3), pp. 449-462.

Monnet, C., H. Bucher 2005: New Middle and Late Anisian (Middle Triassic) ammonoid faunas from northwestern Nevada (USA): Taxonomy and biochronology. - Fossils and Strata, 52, pp. 1-121.

Monnet, C., P. Brack, H. Bucher, H. Rieber 2008: Ammonoids of the middle/late Anisian boundary (Middle Triassic) and the transgression of the Prezzo Limestone in eastern Lombardy-Giudicarie (Italy). - Swiss Journal of Geosciences, 101, pp. 61-84.

Mundil, R., P. Brack, M. Meier, H. Rieber, F. Oberli 1996: High resolution U-Pb dating of Middle Triassic volcaniclastics: Time-scale calibration and verification of tuning parameters for carbonate sedimentation. - Earth and Planetary Science Letters, 141, pp. 137-151.

Mundil, R., J. Pálfy, P.R. Renne, P. Brack 2010: The Triassic time scale: New constraints and a review of geochronological data. - In: Lucas, S.G. (Ed.): The Triassic Timescale. Geological Society, London, Special Publications, 334, pp. 41-60.

Ozsvárt, P. 2012: Blooming and accelerated evolution of radiolarians during the Middle Triassic (Anisian-Ladinian radiolarians from the Seceda core and from Balaton Highland, Hungary). - In: O'Dogherty, L. (Ed.): $13^{\text {th }}$ Interrad. Radiolaria Newsletter, Cadiz (Abstract), p. 98.

Pálfy, J. 2003: Volcanism of the Central Atlantic Magmatic Province as a potential driving force in the end-Triassic mass extinction. - In: Hames, W., J.G. Mchone, P. Renne, C. Ruppel (Eds): The Central Atlantic Magmatic Province: Insights from Fragments of Pangea. Geophysical Monograph, 136, pp. 255-267.

Pálfy, J., R.R. Parrish, K. David, A. Vörös 2003: Mid-Triassic integrated U-Pb geochronology and ammonoid biochronology from the Balaton Highland (Hungary). - Journal of the Geological Society, London, 160, pp. 271-284.

Parnes, A. 1986: Middle Triassic cephalopods from the Negev (Israel) and Sinai (Egypt). - Geological Survey of Israel, Bulletin, 79, pp. 1-59.

Payne, J.L., D.J. Lehrmann, S. Christensen, Jiayong Wei, A.H. Knoll 2006: Environmental and biological controls on the initiation and growth of a Middle Triassic (Anisian) reef complex on the Great Bank of Guizhou, Guizhou Province, China. - Palaios, 21(4), pp. 325-343.

Russo, F. 2005: Biofacies evolution in the Triassic platforms of the Dolomites, Italy. - Annali dell’Università degli Studi di Ferrara, volume speciale (2005), pp. 33-44.

Senowbari-Daryan, B., R. Zühlke, T. Bechstädt, E. Flügel 1993: Anisian (Middle Triassic) buildups of the Northern Dolomites (Italy): The recovery of reef communities after the Permian/Triassic crisis. Facies, 28, pp. 181-256. 
Silberling, N.J., K.M. Nichols 1982: Middle Triassic Molluscan fossils of biostratigraphic significance from the Humboldt Range, northwestern Nevada. - Geological Survey Professional Paper, 1207, pp. $1-77$.

Stampfli, G., G. Borel 2002: A plate-tectonic model for the Paleozoic and Mesozoic constrained by dynamic plate boundaries and restored synthetic oceanic isochrons. - Earth and Planetary Science Letters, 196, pp. 17-33.

Stiller, F., H. Bucher 2008: Anisian ammonoids from Qingyan, southwestern China: Biostratigraphical implications for the age of the Qingyan Formation. - Swiss Journal of Geosciences, 101, pp. 547-562.

Tozer, E.T. 1981: Triassic Ammonoidea: Classification, evolution and relationship with Permian and Jurassic forms. - In: House, M.R., J.R. Senior (Eds): The Ammonoidea. Systematics Association Special Volume, 18, pp. 65-100.

Tozer, E.T. 1994: Canadian Triassic ammonoid faunas. - Geologic Survey of Canada Bulletin, 467, pp. $1-663$.

Velledits, F., Cs. Péró, J. Blau, B. Senowbari-Daryan, S. Kovács, O. Piros, T. Pocsai, H. Szügyi-Simon, P. Dumitrică, J. Pálfy 2011: The oldest Triassic platform margin reef from the Alpine-Carpathian Triassic, Aggtelek, NE Hungary. - Rivista Italiana di Paleontologia e Stratigrafia, 177(2), pp. 221-268.

Vörös, A. 1998: A Balaton-felvidék triász ammonoideái és biosztratigráfiája (Triassic ammonoids and biostratigraphy of the Balaton Highland). - Studia Naturalia, 12, pp. 1-105.

Vörös, A. 2002: Paleoenvironmental distribution of some Middle Triassic ammonoid genera in the Balaton Highland (Hungary). - Abhandlungen der Geologischen Bundesanstalt, 57, pp. 479-490

Vörös, A. (Ed.) 2003: The Pelsonian Substage on the Balaton Highland (Middle Triassic, Hungary) Geologica Hungarica, series Palaeontologica, 55, pp. 1-195.

Vörös, A., T. Budai, I. Szabó 2009: The base of the Curionii Zone (Ladinian, Triassic) in Felsőörs (Hungary): Improved correlation with the Global Stratotype Section. - Central European Geology, 51(4), pp. 325-339.

Walker, T.D., J.W. Valentine 1984: Equilibrium models of evolutionary species diversity and the number of empty niches. - American Naturalist, 124, pp. 887-899.

Watson, A.J. 1997: Volcanic iron, $\mathrm{CO}_{2}$, ocean productivity and climate. - Nature (Scientific correspondence), 385, pp. 587-588.

Zakharov, Y.D., A.M. Popov 2014: Recovery of brachiopod and ammonoid faunas following the end-Permian crisis: Additional evidence from the Lower Triassic of the Russian Far East and Kazakhstan. - Journal of Earth Science, 25(1), pp. 1-44. 